\title{
Viticulture, Wine Production, And Agriculture In Armenia: Economic Sectors In Transition
}

\author{
Nancy J. Scannell, (E-mail: scannell@uis.edu), University of Illinois at Springfield \\ Judy G. Newton, (E-mail: jnewton@aua.am), American University of Armenia \\ Rubina Ohanian, (E-mail: rubina@mindspring.com), Accenture and American University of Armenia
}

\begin{abstract}
This paper focuses on perhaps the oldest branches of economic activity of Armenia - viticulture and wine production. Accounts of vines and wines in Armenia are part of a larger story of the country's agriculture industry. This paper pulls together the historic landscape and present state of affairs of the industries, revealing the significant roles agriculture, viticulture and winemaking have played in shaping Armenia and that they continue to play in sustaining the country's standard of living. From ancient roots, through a transitional era of privatization and into modern times, the story of agriculture as a whole, grape-growing specifically, and wine production in Armenia is one of survival - much like that which characterizes the lives of the Armenian people themselves across scores of centuries.
\end{abstract}

\section{Introduction}

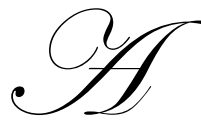
pattern typical of virtually all countries in transition is the volatility of Gross Domestic Product (GDP), and Armenia is no exception; for over a decade Armenia's economic situation can be characterized as one of recovery from economic and political crises and instability (Irs, 2000, p. 9). One positive response to the crises was the emergence of organizations dedicated to improving conditions in the country. The American University of Armenia's (AUA) Center for Business Research and Development (CBRD) in the College of Business and Management (CBM), was established in 1992 to assist Armenia and the surrounding regions with economic development and their transition to a market economy (AUA, 2001). Armenia's Independence Day, September 21, 1991, coincided with the first day of instruction at AUA in the capital city of Yerevan (AUA, 20012003). Under the auspices of CBRD, and with contributions from assistants: Christina Dombayan, Lusine Poghosyan, and David Janibekyan, the authors gathered information on one of the oldest branches of economic activity of Armenia, viticulture and wine production, as well as agriculture as a whole.

\section{Historic Armenia}

Armenia, is one of the most ancient countries in the world, existing since the times of Babylon, Assyria and Egypt. In $301 \mathrm{AD}$, Armenia became the first country in the world to adopt Christianity as its official religion (Decaye and Iskandaryan, 2000).

According to the History of the Armenians by Movses Khorenatsi in 2107 B.C., the legendary archer, Haik, defeated the army of the Assyrian King Belus and established the first Armenian kingdom. In 1824 B.C., the Armenian princedoms united and came under one authority thus giving birth to the geographic and political concept of Armenia. The first indications of Armenia can be traced in Sumerian cuneiform inscriptions dating back to the $3^{\text {rd }}$ millennium B.C., and the Hittites testify to the existence of a country called Hayasa, which is believed to be the cra-

Readers with comments or questions are encouraged to contact the authors via email. 
dle of Armenia. The legendary country consisted of kingdoms of over 60 tribes and included hundreds of towns. The Armenian kingdom is referred to as Ararat kingdom in the Bible. Archeological excavations in the 1950s on the Arin Berd hill within Yerevan city limits revealed a unique and highly developed civilization in the Araratian kingdom of Urartu (Ararat) (Ministry of Industry and Trade, 1998, p. 3).

Armenia was, for most of its history a rural society, with few cities of its own. Yerevan remained a garrison town of 12,500 inhabitants, more than half Muslim, and a place of low, flat-roofed houses and lush walled gardens, until the $20^{\text {th }}$ century (Kiesling, 2001, p. 7-9).

\section{Economy in Post-Soviet Armenia}

In the two years after gaining independence from USSR in 1991, Armenia endured a severe collapse of output and hyperinflation. These adverse developments were precipitated by the loss of traditional economic ties and internal trading system due to the break-up of the Soviet Union; the shift toward market-related, rather than controlled prices as part of the transition to a market economy; civil disturbances in Georgia, a major supply route; and the Nagorno-Karabagh conflict, which led to a 1989 economic blockade imposed by Azerbaijan and Turkey (IMF, 1998, p. 4).

In the first two years of independence, 1992-1993, inflation was extremely high, productivity and national income dropped dramatically, and the national budget ran large deficits (Library of Congress, 1994). Since mid1994, with financial support from Bretton Woods Institutions (BWI) and bilateral donors, a comprehensive program of macroeconomic stabilization and structural reform had been implemented in Armenia. Following 2 years of sustained implementation of tight fiscal and monetary policies, hyperinflation was eliminated, the decline in real wages contained, and GDP grew: 5.4\% (1994); 7\% (1995); 5.8\% (1996); 3.1\% (1997); $7.2 \%$ (1998) and 3.3\% (1999). Despite massive financial injections and interventions from the World Bank, IMF and other international financial institutions, the overall social situation of the country remains deplorable. Moreover, the growth of GDP per capita has not entailed any perceptible improvement of the standard of living in Armenia. Rather, polarization of the society is deepening, disparities are growing among various social strata. The Gini coefficient for Armenia is more than twice higher (0.602 in 1996 and 0.690 in 1998/99) than the average of the European Union (approximately 0.3), which shows the inequality of distribution of the national income. More than $53 \%$ of GDP per capita generated in the country is consumed only by $10 \%$ of the population, while the poorest $10 \%$ get only $0.3 \%$ of the total income per capita (UNDP, October, 2000).

Macroeconomic stability in Armenia was not observed until 1995 (Falcetti, Raiser and Sanfey, July 2000, p. 19). Experts believe Armenia needs several years of double-digit growth to return to the level of its preindependence economy. Source: Noyan Tapan 7-20 (Armenian Assembly of America, July 20, 2001).

\section{Armenian Viticulture and Wine - Ancient Roots}

In a primitive state, a vine is a liana. Some researchers claim that it is very difficult to date the appearance of the first cultivated vines, and that, geographically, the Trans-Caucasian countries of Armenia and Georgia seem to be the birthplace of viticulture (Sopexa, 2000). According to another source, the origins of viticulture are so remote in time that nothing certain can be known concerning them. By 3000 B.C. at the latest and probably much earlier, viticulture is thought to have come down from ancient Armenia, eventually reaching an advanced stage of sophistication in the states of Mesopotamia, in all the lands of Syria and Phoenicia, and in the Egyptian Delta (Veremis, 1998).

One historian cites 7000 B.C. as a starting point in the Middle East, where conditions necessary for organized winemaking are said to have arrived. The ice age having passed, humans had learned how to domesticate a plant (barley). Equally important at that time was the noted invention of pottery, which would serve as the first wine containers. The historian claims that in 6000 B.C. Armenia winemaking appears, as well as the first vineyards, where domesticated Muscat vines were grown (McMillin, 2000).

Ancient rock inscriptions were found in the town-fortress and military/administrative center of Urartu (now 
called Ararat), Erebuni, founded in 782 B.C. on the territory of Armenia's present capital city of Yerevan. Archeological excavations not far from Yerevan, placed in the period 1949-1950 by academician and author, B. Pyotrovsky, established that vine-growing and wine-making were developed in Armenia in the $7^{\text {th }}$ century B.C. In those times vine-growing and fruit-growing had a broad presence in the Urartu Kingdom. The richest evidence of ancient agricultural production in Armenia was discovered during excavation of the $5^{\text {th }}$ century B.C. town of Tishebaini (now called Karmir Blur or 'Red Hill') in the Armenian upland region, specifically in the Ararat valley - now known as the Republic of Armenia. During the kingdom's excavations of Karmir Bloor were detected karases (a karas is a very big argil jug which is usually buried under ground), funnels, candles, sickles, pitchforks, and inscriptions, which indicate that vineyards and fruit yards had existed on the right bank of Hrazdan river, a river that runs through Yerevan. Also unearthed in the Urartu Kingdom was sulfur, signifying that in ancient times wine manufacture operated at an advanced level. Vine-growing and wine-making enjoyed great celebrity, and rulers of the State Urartu supported the industry by building irrigation channels, terraces and other production accessories. From the text of cuneiform it is understood that wine and vineyards possessed religious significance as well; grapes and wine complemented sheep in sacrificial offerings. They were used also as medical remedies - chronicled at Matenadaran Armenia's manuscript library and repository for Armenia's medieval written culture - contemporary records, manuscript 413, 6286 - (Kasoomov and Kasoomyan, 1998, pp. 4-7).

\section{Armenian Landscape}

With 8 geographic, 7 climate, 9 altitude, and 16 soil zones; over half of all plant species in the Transcaucasus (bordering Iran, Turkey and parts of Asia; Webster, 1985); and two-thirds of all bird species found in Europe, Armenia is a stunning biotops region. Armenia's rich diversity of terrain includes Dry Sub-Tropic, Mediterranean, Desert, Semi-Desert, Mountain Steppes, Mixed Forest, Sub-Alpine and alpine vegetation zones. The diversity is due in part to Armenia's weather system, which mixes moisture from heavy snowfalls in the mountains and the Black and Caspian Seas with hot blasts of air from the Syrian and Iranian plateaus (Ney, 1997).

\section{Land Allocation to Grapes}

The grape is the most widely planted fruit crop in the world, covering an area of approximately 10 million hectares. It grows from temperate to tropical regions, but most vineyards are planted in areas with temperate climates. The most concentrated cultures are in Europe. In 1983, the United States ranked seventh in grape acreage worldwide. Grapes we also grown widely in countries of the Southern Hemisphere (Veremis, 1998).

In thousand of hectares [ 1 hectare equals 10,000 square meters or 2.471 acres. (Guralnik, p. 645)], the surface area allocated to sowing grapes on Armenian land has diminished precipitously over the past decade. From 1990 to 2000, surface area devoted to grapes slid by 49\%, as evidenced in the data: 29.2 (1990), 27.0 (1991), 25.0 (1992), 25.3 (1993), 25.5 (1994), 23.2 (1995), 21.9 (1996), 17.8 (1997), 15.8 (1998), 15.8 (1999), and 15.0 (2000) (Synthesis, 2001, p. 118).

\section{Grape Output}

Viticulture was first jeopardized during the soviet period according to anti-hard-drinks "Prohibition Laws" introduced in 1985. While fighting against hard drinking, a large area of vineyards has been destroyed subject to orders and instructions from Moscow, thereby old as well as young vineyards were sacrificed. During the final decade of the Soviet period, viticulture development was carried out by the Ministry of Agriculture, and the planning of winemaking production has been undertaken by the Ministry of Food Industry. The table below presents the dynamics of viticulture development in Armenia during the last decades of the Soviet period (source: Amyot, 2000, p. 11).

\begin{tabular}{l|l|l|l|l} 
& $\mathbf{1 9 7 0}$ & $\mathbf{1 9 8 0}$ & $\mathbf{1 9 9 0}$ & $\mathbf{1 9 9 9}$ \\
\hline Total Area of Vineyards (Hectares) & 36,000 & 36,200 & 25,200 & 15,800 \\
\hline Including: Mature Vineyards & 29,100 & 28,400 & 24,200 & 15,100 \\
\hline
\end{tabular}
Although Armenia continues to depend heavily on food imports and humanitarian assistance, the produc- 
tion of grains, vegetables and milk had increased during the mid-1990s. However, the production of grapes, a traditional product, had declined sharply owing to the fall in output of the wine-based agroprocessing sector, as wine producers had been unable to compete in traditional or new markets in light of the out-dated technology in use (IMF, April 1998, p. 5).

In thousand of tons, from 1990 to 1999 , national output of grapes according to another source has declined by $20 \%$ as the data show: 143.6 (1990), 191.2 (1991), 142.1 (1992), 134.9 (1993), 212.4 (1994), 154.9 (1995), 158.5 (1996), 107.7 (1997), 106 (1998), and 114.8 (1999). In 1990, the state accounted for the bulk of total grape output in Armenia, leaving private production at $13 \%$ of total grape output. However, after 1990, land privatization took hold in Armenia, and the private sector output surged as a percent of (the still meager) total grape output: 98\%(1991), 99\% (1992), 99\% (1993), 99\% (1994), 99.5\% (1995), 99.37\% (1996), 99.72\% (1997), 99.9\% (1998) and 99.9\% (1999) (Synthesis, 2000, p. 126).

\section{Grape Yields}

Arable land in Armenia is limited. The country is mountainous, with only $28 \%$ of land below 1500 meters altitude. Topography and climatic conditions, soil fertility and the access to irrigation water vary greatly and affect yields. Although most of the land had been privatized into small land holdings since the breakup of the Soviet Union in 1991, the new and often very small farmers received little or no institutional backup and extension services. As a result of the chronic shortage of quality seeds, the deterioration of the irrigation system, and the lack of capital, the average yield of grain and most other crops remains low. The 1998-1999 drought has further reduced the national crop production and undermined other agricultural production in 1999 (FAO, 2000).

Grape yields per hectare, in thousand tons, fell from 7815 in 1991 to 7310 in 1996 . The subsequent four years registered yields of 6067, 6752, 7325 and 7480, respectively (Ministry, 2001). Available data from years 1991 to 1998 show that the private sector accounts for the lion's share - and slightly increasing share - of total grapesown hectares of land in Armenia: 96\% (1991), 98\% (1992), 98\% (1993), 98\% (1994), 98\% (1995), 98\% (1996), 99\% (1997), and 99\% (1998) (Synthesis, 2000, p. 125).

\section{Armenian Grape Prices}

During the period 1995 to 1999 annual prices of grapes fell significantly due to structural changes that took place in agriculture over the last couple of years in response to the market place. The main shift was towards products in high demand that did not include grapes. Also, domestic food prices were affected by global market conditions including food imports. In addition, the limited consumer demand for grapes and other agricultural products was a direct function of the low incomes of the Armenian population, aggravating the crisis in agriculture (Irs, 2000, pp. 21-22).

\section{Armenia Wine Varieties}

Armenia is rich in fruits. Grapes of some 40 variety grow throughout the country, although mainly on the Ararat valley. Due to the rich experience of viticulture and winemaking, the Armenian wine is of high quality (Elitar, 2001). There are in all between forty and fifty species of true grape-vines, one native to Europe, twelve to Asia, and thirty-five to N. America (Veremis, 1998). Armenia produces over 50 different brands of wines, and 7 brands of champagne and sparkling wines years (Khudaverdyan and Sargsyan, 1999, p. 193).

\section{Local Consumption of Wine}

Although Cognac is its best-known beverage product, Armenia produces a remarkable variety of grapes under soil and climate conditions perfect for fermenting excellent dry wines. Nonetheless, the largest selections of wines are semi-sweet to sweet wines. Areni grape wine is arguably the most popular wine in Armenia. Armenians prefer such wines, choosing harder drinks like cognac or inexpensive vodka (roughly \$1 USD per high-alcoholcontent 500-ml bottle) over wine at dinners. Other spirits that compete for Armenian consumers are imported gin, 
whiskey, scotch whiskey and tequila which are priced significantly higher - more than $\$ 30$ USD per bottle (Ney, 1997).

\section{Wine Output in Armenia}

From an historical perspective, because of Arab, Turkish and Iranian invasions, Armenia, which had occupied a vast territory from the Black Sea to the banks of the Tigris and Euphrates rivers at one time, had its borders sharply reduced, and hence its cultivation of grapes plummeted (Kasoomov and Kasoomyan, 1998, pp. 4-7). In post Soviet times, Armenia is facing a new form of assault on its wine production industry. The interruption of main transport routes, loss of traditional markets, and a complicated financial situation provoked a decline in production volumes during the mid-1990s (Embassy, 1997).

Measured in thousand decaliters [one decaliter is a measure of capacity/volume and is equals to 10 liters or 2.64 gallons liquid measure, or 9.08 quart dry measure (Guralnik, 1984, p. 364)], wine production took a nose-dive over the years 1990 to 2000. The data clearly evidences this: 4191 (1990), 4326 (1991), 2498 (1992), 2735 (1993), 2271 (1994), 1215 (1995), 732 (1996), 336.5 (1997), 152.6 (1998), 431.1 (1999), and 256.1 (2000) (Synthesis, 2001, p. 115).

\section{Trade in a Landlocked Country}

Landlocked countries are inaccessible by deep-sea ocean vessels. Import and export goods must be transshipped in other countries by means of truck and/or rail and/or inland waterways (river, canal or lake). In Soviet times, Armenia's transship seaports were Batumi, Georgia and Mersin, Turkey (Export 911, 2001). Armenia is one among scores of landlocked countries in the world. Its systems of communication and transport by road and rail, as well as its oil and gas pipelines are dependent on neighboring states. Georgia and Azerbaijan are situated to the north and east, respectively. Armenia also borders Turkey to the west, Nakhichevan (an Azerbaijan enclave) to the southwest and Iran to the south. Before the imposition of blockades (further discussed below), Armenia's main land routes to the other Soviet Republics were through Azerbaijan (Ulbricht, 1995, p. 7).

War between Azerbaijan and the Armenians of Nagorno-Karabagh has been accompanied by the blockade of all railroad and energy pipelines to Armenia. In the Soviet era, $85 \%$ f Armenia's imports and exports were transported over a rail line running from Yerevan through Baku to Russia. This route has been blocked by Azerbaijan since 1989. Consequently, Armenian industrial output had been brought to a virtual standstill. Also, the state of civil war in Georgia had led to an unsteady flow of rail traffic to Armenia. Even humanitarian assistance unloaded from ships at the port of Batumi has been repeatedly held up in Georgia. The only functioning gas pipeline, which runs from Russia to Armenia, had been repeatedly damaged in the Azer-populated region of Marneuli in Georgia. Furthermore, Turkey supports Azerbaijan in the Nagorno-Karabagh war by embargoing trade with Armenia and by keeping its borders with Armenia closed or at best severely restricted. The embargo included both air and land routes in addition to humanitarian assistance since April 1993. The result was an added blockade imposed on Armenia's western border (Adalian, 1994, p. 13).

Roads and rail routes through Georgia to the Black Sea, and a road across the narrow border with Iran were left as alternatives, along with built-up air connections (Ulbricht, 1995, p. 7). That said, the transportation facilities between Armenia and Iran are underdeveloped and incapable of sustaining Armenia's economic and energy needs (Adalian, 1994, p. 13).

The Sharafian Consulting Center was hired by the World Bank to administer a survey of 200 Armenian private businesses in May 1998 to expose the main constraints for their operations and growth. Although $96 \%$ of businesses surveyed were selling only to Armenian markets and $68.7 \%$ of the businesses surveyed bought their inputs exclusively locally, the blockade of rail routes to Russia and the CIS (through Azerbaijan and Georgia) was perceived as an indirect, but very important factor adversely affecting their businesses, contributing to insufficient or unstable demand (Sharafian, 1999, pp. 2, 3, 13).

As of January 1999, Armenia has railway and road connections to the port at Poti in Georgia. Exports to 
Russia and other CIS countries are generally shipped from Poti to Novorosisk in Russia and then transferred by rail. The two direct rail connections by rail to Russia and the CIS are not open either through Azerbaijan (due to conflict in Karabagh) or through Georgia (due to the conflict in Abkazia). Marketing constraints are possibly the chief obstacle to increasing farm income and the most difficult for farmers to overcome. Appropriate marketing and transport infrastructure for small farmers is lacking. The geopolitical constraints, (pending resolution of the issue of Nagorno-Karabagh) and the uncertain timing of arrival and of transshipment of goods at Poti, make export of fresh produce virtually impossible, except by air (FAO, 2000). The red tape involved in the load and reload of cargo inflates shipping costs, thus discouraging exports (Sharafian, 1999, p. 13).

\section{Wine and Other National Exports of Armenia}

Armenia is a net-exporter of fruits, including its most important fruit crop, grapes (Adalian and Masih, July, 1996, p. 44). Armenia was forced to rely mainly on aviation and a few unstable, low-capacity and insecure land connections via Georgia and Iran (EBRD, 1998, p. 15). Wine export was but one casualty of a multi-sector export plunge. The unrelenting blockade imposed upon Armenia as a result of the armed conflict between the Republic of Azerbaijan and the enclave of Nagorno-Karabagh; the devastating earthquake of 1988 that destroyed infrastructures and killed 25,000 persons; the choking off of Armenia's major northern trade route due to civil conflict in Georgia; and the considerable economic dislocation associated with the disintegration of the Soviet Union, culminated in sharp output reductions, falling incomes, reduced trade flows, severe energy shortages, and scarcity of food and other consumer goods in Armenia (DCR, 1996).

In 1997, Armenia registered a 25\% drop in exports. The following year, 1997, was characterized by some analysts as a year of stagnation for Armenia (DCR, 1997). The economic data for 1998 showed a fairly good picture of the Armenian economy, including a slight improvement in the trade deficit. Still, the growth rate of both exports and imports slowed in 1998. Imports were almost flat, while exports fell by $4 \%$. This reflected both the slowdown in international trade and the declining price of commodities (DCR, 1998).

In January-June 2001, despite substantial growth in exports and decrease in imports, Armenia's trade deficit remains large, with the country's imports more than double the size of its exports. Armenia imported goods worth $\$ 395.3$ million, while exports stood at a modest $\$ 155.8$ million. The share of Armenia's trade with post-Soviet countries, primarily Russia, increased to $25 \%$. The countries of the European Union remain Armenia's largest trading partners, with their share at just under 30\% (Armenian Assembly, August 17, 2001).

Closed borders, blockades, and war-damaged infrastructure provide only a partial explanation for the dramatic drop in exports. Even in areas where no serious political obstacles to commerce exist, there are institutional, bureaucratic and structural barriers to trade that will need to be lifted, before trade will expand and the countries can reap any substantial economic benefits from a re-opening of borders (World Bank, 2000).

\section{Agricultural Output in Armenia}

Agriculture, always an essential sector of the Armenian economy, experienced a rise of 50 to $55 \%$ in the share of GDP as a result of the sharp decline in the industrial sector. In 1997 the sector consisted of 314,000 individual private farms, 1600 private cooperative farms, and approximately 150 large state and private agricultural enterprises. The Ministry of Agriculture and Food is responsible for implementing agricultural policy and administrates the activity of state-owned agricultural and food processing enterprises (Embassy, 1997). As of 2000, agriculture contributes about one-third to Armenia's GDP and accounts for $42 \%$ of employment (FAO, 2000).

Agricultural productivity in Armenia is heavily influenced by its geographical setting and climate. Armenia is situated in a high mountainous zone, with $40.5 \%$ of its territory sitting 2,000 meters above sea level. For the most part, it is poor in arable land; on a per-capita basis, 0.4 hectares of land is suitable for agricultural purposes, and 0.14 hectares is arable land. Overall only $10 \%$ of land is arable. The area receives little precipitation, with 2,400 cubic meters of water annually per-capita as compared with the annual per-capita average of 18,000 cubic meters in the former Soviet Union. There are some regions in Armenia that are arable and extremely fertile; most of these areas 
are concentrated in the Ararat Valley. This area produces a significant amount of the total agricultural output of the republic. Grapes and citrus, especially among the fruits, as well as grain, potatoes, vegetables, and sugar beets are among Armenia's chief crops. Vineyards near Yerevan are famous for brandy and other liqueurs as well (Adalian and Masih, July, 1996, p. 44).

At current prices and as a percentage of GDP, agricultural output plummeted from years 1994 to 2000 as the data show: $43.5 \%$ (1994), 38.7\% (1995), 34.8\% (1996), 29.4\% (1997), 30.8\% (1998), 26.2\% (1999), and 22.5\% (2000) (Synthesis, 2001, p. 107). To address institutional shortcomings which exacerbate the plight of Armenian agriculture, the government has drawn up a strategy for the development of an enabling environment for agriculture, and passed a large number of laws. But in recent years progress in key areas has stagnated due to political turmoil and inaction. Because of this instability in the first five months of 2000 , the pace of growth in the agricultural sector decreased significantly. Lack of basic farming knowledge and management skills is a major bottleneck. The use of fertilizers, improved seeds, and pesticides is limited and are usually acquired by barter (FAO, 2000).

\section{Private Enterprise Development and Cooperatives}

The creation and development of the private sector in the Armenian economy began in 1985 with the Perestroika reforms in the USSR. Cooperatives (the only legal enterprise form of private entrepreneurship at that time) were created in Armenia as early as 1987. Local authorities offered a strong resistance and reluctance to the cooperative movement both in Armenia and in the other (former Soviet Union) FSU republics. In Armenia however, the population had always demonstrated a strong traditional propensity for entrepreneurship and readily overcame the opposition. The most active and successful cooperatives were in textile, shoemaking, food processing, and trade. According to the population ratio, Armenia exceeded all other FSU republics in private sector development. Within four years 16,000 cooperatives were established in Armenia - 25\% of those in manufacturing. A project was proposed for establishing a cooperative bank for small farmers. However, public investments can only cover a relatively small share of the sector needs. The agricultural and food processing sector requires a significant amount of private investments, both foreign and domestic. The main objective of the Government in sector policy is to create a favorable environment for private investments and profitable returns (Embassy, 1997).

\section{Armenian Land Privatization}

Armenia was the first former Soviet Republic to introduce a comprehensive land privatization program. This was completed in 1991, and Armenia, alone among NIS countries (Newly Independent States, also called CIS or Commonwealth of Independent States), put state-owned land in the hands of individual farmers. Armenia's Parliament began passing laws to implement this reform slowly in summer1990, beginning with a law on private property that resulted in the adoption of the land code of January 30, 1991. Within a two-month period, four-fifths of all cultivated land was privatized, at a time surpassing every other former Soviet republic - even Russia, which up to that point had done little more than publicize its intent to implement reform. On January 1, 1993, the number of privatized farms stood at 243,000 with a total area comprising more than 209,300 hectares. In 1992, the number of privatized farms totaled 164,500 . Land privatization initially resulted in a crop output rise of $30 \%$, and a $15 \%$ increase in agricultural production, but in subsequent years, output has fallen largely due to the effects of the blockage on the economy (Adalian, 1994, p. 44). Armenia adopted the first private property law in the NIS in February 1996 (Tacis Project AR 10, May 1999). Land privatization was the single most important factor contributing to household food security during 1991-1995 (FAO, 2000).

In an increasingly market-driven economic environment, privatization had the potential to play a positive role in reviving the traditionally famous wine production industry in Armenia. Nonetheless, privatization of land was beleaguered by serious negative repercussions. Even under normal circumstances, poor subsistence farmers could barely produce enough for their own household food consumption. Armenia is a highly food insecure country with $28 \%$ of the population undernourished. The rate of recovery from the shocks of the transition differs among farms, depending on their natural endowment, proximity to solvent markets and management. In mountainous, remote, or insecure areas, the limited crop/market choice and the need to ensure household food security often traps farmers in low-input low-output scenarios (FAO, 2000). 
Before privatization, 886 large state-owned agricultural enterprises accounted for $66 \%$ of the gross agricultural output, while individual part-time small farms produced the remaining 34\% (Embassy, 1997). The land in Armenia, privatized immediately upon acquiring independence, allowed for the return of farmland to farmers. Some 320,000 farmers had been allocated small farms - with scattered parcels of land - averaging between 1.4 - 1.7 hectares of arable land. In practice, given emigration and the ability to lease land from the state reserve, some farmers farmed considerably larger plots. The bulk of agricultural land has been privatized but there was little support for small land holdings. Farmers, like the rest of the population, had been impoverished by hyperinflation in the early nineties, which limited earning opportunities. Access to formal credit for many small farmers remains difficult, not because credit is unavailable but because both collateral and sustainable disbursement opportunities are limited. As a result, access to quality inputs and machinery is difficult (FAO, 2000). The livestock and a substantial part of agricultural equipment were privatized shortly thereafter. However, delays with the privatization of the food processing industry and the sectors catering to farming needs resulted in a situation where the country still was not able to establish adequate structures for technical servicing of farms and for the sale of produce. The creation of such structures as well as the resolution of an important problem in the Armenian context, irrigation, became imperative (Khudaverdyan and Sargsyan, 1999, p. 83-84).

In 1991-1992, the process of land distribution was separated from farm restructuring. In principle the members of a collective farm had the option of maintaining the previous structure. In practice, however, the members opted for individual farming, and most collective and state farms were dismantled in 1992 and 1993 (Aghamian, 1997, p. 15). By the end of $1993,69 \%$ of plow land, $79 \%$ of perennial plantations, and $44.1 \%$ of hayfields were privatized and widely dispersed among new owners. The remaining $20 \%$ of land was reserved under state control for further distribution. Emerged individual farms were generally small (average $1.26 \mathrm{ha}$ ), and land insufficiently small to derive economies of scale. Simultaneously 350,000 head of cattle were sold to private owners. Approximately $30 \%$ of remaining assets (real estate, transport. machinery. and equipment) were also privatized. As a result, agricultural outputs gradually increased in the subsequent three years (Embassy, 1997).

The major share of supply, storage, processing, and marketing enterprises remained under state control, and deceleration of their privatization considerably hampered development for the three years following land privatization. In 1994, the Government corporatized and introduced for privatization the major part of state-owned enterprises in the agricultural sector. By the end of 1995, 77 enterprises had been sold to private owners. State-owned enterprises mainly carried out activities on agrotechnology, fertilizer and chemical supply, seed growing, pedigree breeding, and water supply (Embassy, 1997).

\section{Recent Natural Crises in Agriculture}

The summer months of 2000 were unusually dry and hot over almost all parts of Armenia accelerating the level of evapo-transpiration and causing deep ruptures in the soil. Total rainfall was nearly $70 \%$ below average in most cases. The country's irrigation systems are largely surface-water based. Ground water is also used in some areas. Snow cover is the main source of source water feeding into the country's river systems. Poor rains and snow cover in 2000 prompted a sharp decline in levels of water in rivers and canals that limited irrigation activities and significantly lowered the water table in most areas. The state of disrepair of irrigation infrastructure and consequent loss of limited water has also exacerbated the problem. Water users associations do not function properly and many farmers simply do not have the cash to pay and so get cut off or left out of the water rota. Subsistence farmers, accounting for as much as $90 \%$ of the farming population in the recently drought-affected areas, are living on the bare minimum and are in danger of starvation (FAO, 2000).

\section{Conclusion}

Since June 1995, Eurasia Foundation has provided short-term loans for businessmen involved in agribusiness, manufacturing, and services in already existing companies to help finance the expansion or upgrade of their operations (Tacis Project AR 10, Annex B, p. 1).

With the recent drought situation, tax revenues are likely to decrease, further undermining the government's 
ability to provide for its most needy and vulnerable citizens through its social welfare program. Introduction of new credit schemes to assist farmers to purchase inputs including livestock feeds, seeds and agro-chemicals are important (FAO, 2000).

The World Bank is looking, in particular, at telecommunications and internet development in the region, not merely for its intrinsic contribution to economic development, but because it offers a new vehicle for facilitating economic cooperation and interaction between individuals, businesses and governments, despite political barriers. In addition, the Internet can play a critical role in breaking down the geographic isolation in the Transcaucasus, and permitting contact with the world beyond their borders. The Bank is also building on the experience of the Trade and Transport Facilitation in South East Europe Project (TTFSE) where international organizations have been working with public and private sector groups in six neighboring states to achieve significant improvements in trade facilitation in a region where wars, political animosities, and economic collapse have destroyed old trade patterns and stymied the establishment of new ones (World Bank, 2000).

The formation of modern agriculture is also hampered by difficulties, both inherited from the former economical system and the newly emerging one. Particularly, the development of agricultural markets is strongly confined by unfavorable financial and pricing situations, with high levels of loan interests, abrupt seasonal changes in demand and prices, and lack of adequate infrastructure, including proper insurance, mutual loans, etc. (Embassy, 1997).

\section{Suggestions for Future Research}

One of the major problems of reviewing developments in agricultural and food production is the absence of data reflecting the complex nature of the ongoing developments. Budget constraints mean that there are inadequate funds and institutional support for data collection. Official data is currently based on the reports of farming organizations and a survey of 7000 small farmers, but actual yields are not measured. Some data could be misleading on account of the overlapping of the private/state economy. For example, while 100,000 hectares of agricultural land are officially reported to be unused, this may not all be lying idle and is quite likely sub-leased for use as pasture. Although official statistics may not reflect actual developments, there is no alternative source on which to base national estimates (FAO, 2000). Thus, a first step to undertaking advanced research in Armenia's viticulture and wine industry is to promote the management and flow of credible information and data.

There were about 14 scientific-research institutes and several associated stations and farms under the Ministry of Agriculture. But for years, research institutes have been under considerable pressure due to the massive reduction in budgetary allocations. The transition to a more farmer-oriented, applied type of research was off to a slow start since scientists were not yet fully aware of the needs of domestic farmers. Also, the scientific and practical specialists working in the institutes have limited links with similar research institutions and specialists from developed countries. New processes for defining the research agenda and linking research with advisory services and farmers need to be developed in order to ensure the relevance of research for agriculture in the emerging market economy (Aghamian, 1997, p. 19). Agricultural research and the limited extension services have not been functioning properly for many years due to budgetary cuts; the Agricultural Research Institute is a case casualty in point (FAO, 2000).

Studies of Armenia's wine and viticulture industries could be directed at improving production, marketing, pricing, distribution and promotional strategies in an effort to bolster their places in the economy, and, ultimately, to raise the standard of living for Armenia's farming communities. Also, given that globalization has come to the table in post-Soviet Armenia, research can be extended to address variables that influence the industry at the international level, including foreign investment and international trade factors. Moreover, since viticulture and wine production in Armenia are among the oldest of all economic activities in the country, advanced research on the fluctuating status of these sectors vis-à-vis Armenia's economic and political cycles over scores of centuries should yield invaluable insights into the inherent nature of these cherished industries. Lessons garnered from the experience within the vine and wine sectors might prove useful for comparative studies with other industries that are enduring similar pains from privatization in Armenia - or in other countries in economic transition. 


\section{References}

1. Adalian, Rouben P., editor; Balian, O., Bedeian, L., Chichmanian, T., DeTrana, U., Hovsepian, A., Khzmalian, T., Masihand Masih, J., Merguerian, E, Szalkowski, K., and Yeghiazarian, N., Armenia Factbook, Office of Research and Analysis, Armenian Assembly of America, 1994, pp. 13, 44.

2. Adalian, Rouben P., editor and Masih, Joseph, R., associate editor, Armenia \& Karabagh Factbook, Office of Research and Analysis, Armenian Assembly of America, July 1996, p. 44.

3. Aghamian, Levon, Agriculture in Armenia, Office of the Agricultural Counselor, Royal Netherlands Embassy, Moscow, Russian Federation, pp. 15, 19.

4. Amyot Exco Armenia, The Armenian Winemaking Industry, Member of Grant Thorton International, Yerevan Brandy Company CJSC, Areni Wine Production Project, Business Plan, 2000, p. 11.

5. Armenian Assembly of America, Armenia this Week, On-line Newsletter, August 17, 2001, (Sources: Noyan Tapan 7-20; 8-13, 16; ArmInfo 8-14), http://www.aaainc.org/armenia_week/weekintro.htm.

6. Armenian Assembly of America, Armenia this Week, On-line Newsletter, July 20, 2001, (Sources: Noyan Tapan 7-20; 8-13, 16; ArmInfo 8-14), http://www.aaainc.org/armenia_week/weekintro.htm.

7. AUA, American University of Armenia, College of Business and Management, Master of Business Administration Information Brochure, Yerevan, Republic of Armenia, 2001, p. 2.

8. AUA, American University of Armenia, General Information Catalog, Graduate Courses and Degrees, draft, 2001-2003, p. 10.

9. Avakian, V., editor, Republic of Armenia; Regions, Communities and Settlements, Democracy Union, Yerevan, 1996, p. 31.

10. DCR, Development Co-operation Reports, Armenia Country Background; Economic and Social Overview, UNDP, 1996, http://ww.undp.am/archive/Dcr/Dcr96/country3.html.

11. DCR, Development Co-operation Reports, Armenia Country Background; Economic and Social Overview, UNDP, 1997, http://ww.undp.am/archive/Dcr/Dcr97/body.html.

12. DCR, Development Co-operation Reports, Armenia Country Background; Economic and Social Overview, UNDP, 1998, http://ww.undp.am/devcoop/Dcr98/33.html.

13. Decaye, Jocelyne and Iskandaryan, Ashot, Tourism Profile, in cooperation with K. Tereshchatova, Armenian-European Policy and Legal Advice Center, Yerevan, September 2000, p. 3.

14. EBRD, European Bank for Reconstruction and Development, Armenia: 1998 Country Profile, EBRD Annual Meeting, Business Forum, Kiev, May 12, 1998, p. 15.

15. Elitar Travel Company, Armenia; Biblical Country of Noah's Ark, Karin-Hrat Co. Ltd., Vbars, Yerevan, Armenia, 2001, p. 5.

16. Embassy of the Republic of Armenia, Investment Opportunities, Washington, DC, May, 1997, http://www.armeniaemb.org/invest.html.

17. Export 911 Worldwide Services, Landlocked Countries and Transshipping Points, http://www.export911.com/e911/ship/landlock.htm.

18. Falciti, Elisabetta, Raiser, Martin, and Sanfey, Peter, Defying the Odds: Initial Conditions, Reforms and Growth in the First Decade of Transition, European Bank for Reconstruction and Development, Working Paper No. 55, July 2000, p. 19.

19. FAO Global Information and Early Warning System on Food and Agriculture World Food Program, Special Report, FAO/WFP Crop And Food Supply Assessment Mission To Armenia, October 5, 2000, http://www.fao.org/WAICENT/faoinfo/economic/giews/english/alertes/2000/SRARM100.htm.

20. Guralnik, David B., editor, Webster's New World Dictionary of the American Language, $2^{\text {nd }}$ Edition, Prentice Hall Press, Simon \& Schuster, 1984, pp. 364, 645.

21. IMF, International Monetary Fund, Republic of Armenia: Recent Economic Developments, IMF Staff Country Report, No. 98/22, 1988, pp. 4, 5, 53.

22. Irs, Instituto per la Ricerca Sociale, Economic Trends Quarterly Issue, January - March 2000, Armenia, European Commission, Director General IA, NIS/Tasis services, July 2000, pp. 9, 21-22. 
23. Kasoomov, Norik B. and Kasoomyan, Levon N., Wines of Armenia, Yerevan, Nairy Publishers, 1998, pp. 4-7 10, 19-20, 57, 59.

24. Khudaverdyan, Konstantin and Sargsyan, Yeghishe, Armenia, A Country and the People, A Guidebook, Vera Movsessian Publisher, 1999, pp. 83-84, 193.

25. Kiesling, Brady, Rediscovering Armenia, Edited by Raffi Kojian, April 2001, pp. 7-9, 71.

26. Library of Congress, Country Studies, Armenia; The Economy, http://lcweb2.loc.gov/cgibin/query/r?frd/cstdy:@field(docid+am0017).

27. McMillin, Fred, The History of Wine, February 07, 2000, http://www.globalgourmet.com/food/wineday/2000/wd0200/wd020700.html.

28. Meredith Corporation, (1985) Webster Encyclopedia, Des Moines, Iowa, Concord Reference Books, p. 173.

29. Ministry of Agriculture and National Statistics Office of Armenia, Trends in Agricultural Production Table, Yerevan, 2001.

30. Ministry of Industry and Trade, General Armenia Information, Republic or Armenia, 1998, p. 3.

31. Ney, Richard L., Tour Armenia; A Complete Information and Travel Kit, CD-Rom, Transworld Resources International, Inc, File E, Content / Nature, Planning, 1997.

32. Norik B. Kasoomov, Norik B. and Kasoomyan, Levon N, Wines of Armenia, Nairy Publishers, Yerevan, 1998, pp. 4-7.

33. Sharafian Consulting Center, Republic of Armenia; Summary Results for Survey of Private Businesses, March 5, 1999, pp. 2, 3, 13.

34. Sopexa Canada Ltd., Vine History; Origins of the Vine, 2000,

35. http://www.vins-france.com/en/abc/pages-sections/histoire/origine.html.

36. Synthesis, Economic Trends Quarterly Issue, January - March 2001, Armenia, European Commission, Director General IA, NIS/Tasis services, July, 2001, pp. 107, 115, 118.

37. Synthesis, Economic Trends Quarterly Issue, July - September 2000, Armenia, European Commission, Director General IA, NIS/Tasis services, November 2000, pp. 125-126.

38. Tacis Project AR 10, A Strategy for the Development of Small and Medium Sized Enterprises in Armenia, IMI International, June 1999, Annex B, p. 1.

39. Tacis Project AR 10, A Strategy for the Development of Small and Medium Sized Enterprises in Armenia, IMI International, May 1999, p. 5.

40. Ulbricht, Carl, Armenian Commercial Law; Foreign Investor's Handbook, Yerevan, 1995, p. 7.

41. UNDP, Briefing Report: Armenia, Semi Annual Report, United Nations Development Program Country Office in Armenia, October, 2000, pp. 5-6.

42. U.S. State Department of Statistics, (1998), Armenia: Productions of Selected Agricultural Products, 19941997, found in IMF Staff Country Report No 98/22, Washington, D.C., April 1998, p. 53.

43. USAID, Armenia Strategic Plan FY 1999 - FY 2003, March, 1999, p. 5, 27, http://www.info.usaid.gov/countries/am/strategic.plan/html/str99pub.htm.

44. Veremis, John, Grape Growing, Ethnobotanical Leaflets, Southern Illinois University Carbondale, October 26, 1998, http://www.siu.edu/ ebl/leaflets/grapes.htm.

45. World Bank, Regional Initiatives in the South Caucasus, http://nweb18.worldbank.org/eca/ eca.nsf/Initiatives/A66C02F0D96CB6D0852568FC005D2A3E?OpenDocument. 
Notes 